\title{
Human Rights and the Same-Sex Marriage Debate in Australia
}

\author{
Bede Harris ${ }^{1}$ \\ ${ }^{1}$ School of Accounting and Finance, Charles Sturt University, Australia \\ Correspondence: Bede Harris, School of Accounting and Finance, Charles Sturt University, Australia. E-mail: \\ beharris@csu.edu.au
}

Received: June 25, 2017

doi:10.5539/jpl.v10n4p60
Accepted: July 14, $2017 \quad$ Online Published: August 30, 2017

URL: https://doi.org/10.5539/jpl.v10n4p60

\begin{abstract}
Australia is currently confronting the issue of whether to legalise same-sex marriage. Thus far debate has been conducted with little reference to human rights theory. This article draws on the theories of John Rawls and John Stuart Mill and analyses whether, by confining the right to marry to heterosexual couples, the law infringes the right to privacy and, conversely, whether the legalisation of same-sex marriage would infringe religious rights of those who are unwilling to provide goods and services to same-sex couples. In so doing, the article adopts a comparative approach, drawing on case law from the United States. The article examines the way in which political debate on the issue has been conducted by the major parties in Australia, and concludes that both the Liberal-National coalition and the Labor party have been motivated by a desire to appease the religious right within their ranks, at the expense of human rights principles.
\end{abstract}

Keywords: Australia, autonomy, discrimination, equality, human rights, marriage, privacy, same, same-sex

\section{Introduction}

How Australia addresses the issue of same-sex marriage raises fundamental questions relating to the values underpinning the law. Yet a striking feature of the same-sex marriage debate has been the lack of focus on rights theory. This article seeks to redress this imbalance by analysing the same-sex marriage issue from a human rights perspective, in recognition of the fact that the ethical quality of law is determined by the values which underpin it and that its text is merely the method by which those values are given effect.

Part 2 of the article summarises the constitutional position and the power of the Commonwealth Parliament to legislate for same-sex marriage. Part 3 discusses the values which ought to underpin the discussion of questions relating to individual freedom, focussing on the theories of John Rawls and John Stuart Mill. Part 4 discusses the question of whether the current prohibition on same-sex marriage constitutes an infringement of fundamental rights, taking a comparative approach through a discussion of decisions by the United States Supreme Court on the right to privacy. Part 5 addresses the claim that recognition of same-sex marriage could cause harm to religious freedom, specifically addressing the argument that businesspeople should be able to reject custom from same-sex couples. Part 6 of the article examines the political history of the same-sex marriage debate in Australia. Part 7 concludes with a discussion of the likelihood that same-sex marriage will be legalised.

\section{The Constitutional Position}

The Commonwealth's legislative capacity in relation to marriage derives from the marriage power contained in $\mathrm{s}$ 51(xxi) of the Constitution. In 2004 the Commonwealth Parliament used this power to insert into s 5 of the Marriage Act 1961 (Cth) a definition of marriage as 'the union of a man and a woman to the exclusion of all others, voluntarily entered into for life'. In 2013 the Australian Capital Territory enacted the Marriage Equality (Same Sex) Act 2013 (ACT), which sought to legalise same-sex marriage in the ACT. In Commonwealth $v$ Australian Capital Territory (Marriage Equality Case), ${ }^{1}$ the High Court unanimously held that the Marriage Equality (Same Sex) Act 2013 (ACT) was invalid on the ground that the Commonwealth Act dealt exclusively with the definition of marriage, and that because the ACT legislation permitted persons of the same sex to marry, it was inconsistent with the Commonwealth Act, and thus void.

Perhaps of even greater significance of the decision was the fact that the court held that the word 'marriage' in $\mathrm{s}$

${ }^{1}$ (2013) 250 CLR 441 
5 of the Commonwealth Act must be given an ambulatory interpretation ${ }^{2}$ - that is, one which evolves through time - and that therefore marriage power contained in s 51(xxi) of the Constitution extends to the making of laws relating to same-sex marriage, even though that would not have been the case when the Constitution was written. ${ }^{3}$ The consequence of this is that the question of whether same-sex marriage should be legalised in Australia lies squarely in the court of the federal Parliament. What values should guide politicians as they address that question?

\section{Values and the Law}

In answering this, we need to recognise that it is but one dimension of the fundamental question which underlies every debate on rights, namely what principles should determine the extent to which the state should impose limits on the autonomy of the individual? Clearly any limitation on whom a person may marry amounts to a restriction on personal choice at the most intimate level, which is why the more fundamental question needs to be addressed. In answering this, it is useful to draw on the theories of two legal philosophers, John Rawls and John Stuart Mill.

Rawls' theory of justice provides a useful tool enabling an objective determination of the content of fundamental rights. ${ }^{4}$ This theory depends on imagining a game in which participants, situated in what is called the 'original position, ${ }^{5}$ are asked to devise fundamental values upon which a society's legal rules will be based. The catch is that the participants operate behind what Rawls called the "veil of ignorance' ${ }^{6}$ - in other words, unaware what their identities will be in that society. Only once they have determined these fundamental values will they know what their gender, race, religion, sexual orientation and financial resources et cetera will be. Rawls concluded that in a condition of uncertainty about social identity, rational participants would agree on what he called the 'liberty principle', namely that each person should have the fullest degree of liberty - that is, fundamental rights - as is consistent with everyone-else's equal liberty. ${ }^{7}$ The beauty of Rawls' theory is that it appeals both to self-interest and to altruism - each person behind the veil will want to maximise the freedom that an individual will be allowed, but would also be keenly aware of the need to protect the rights of minority groups from the will of the majority, in case he or she should find him or herself in one of those minority groups when identities in the society are revealed.

An important qualification Rawls placed on his liberty principle is that liberties should be enjoyed only in so far as they were consistent with the equal liberties of others. This echoes the harm principle of John Stuart Mill, which is that the only ground upon which a person's freedom should be restricted was to prevent harm to someone-else - as Mill stated ${ }^{8}$

The only purpose for which power can rightfully be exercised over any member of a civilised community, against his will, is to prevent harm to others.

and similarly that ${ }^{9}$

The only freedom which deserves the name, is that of pursuing our own good in our own way, so long as we do not attempt to deprive others of theirs, or impede their efforts to obtain it.

In the legal context, this means that what limits should be imposed on rights must be determined through a process of balancing.

If we apply Rawls' rational equal liberty principle and Mill's harm principle to the debate on marriage equality, what result do we arrive at?

\section{Does the Prohibition on Marriage Equality Offend against Liberty?}

In addressing the issue from a Rawlsian perspective, the question we need to ask is whether the exclusion of same-sex couples from the opportunity to enter into marriage infringes a right which would be recognised as requiring protection by rational participants formulating the rules for a future society.

\footnotetext{
${ }^{2}$ At 455-63.

${ }^{3}$ For analysis of the court's interpretation of the word 'marriage' see Kirby, M. (2016). The ACT Marriage Equality Case - Losing the Battle but Winning the Constitutional War. Southern Cross University Law Review 18, 79-91 at 86-91.

${ }^{4}$ Rawls, J, (1972). A Theory of Justice. Oxford: Clarendon Press.

${ }^{5}$ Ibid $17-22$.

${ }^{6}$ Ibid $136-42$.

${ }^{7}$ Ibid 61-2.

${ }^{8}$ Grey, J. and Smith, G.W. (eds) (1991). J S Mill 'On Liberty' in Focus. London: Routledge at 30-1.

${ }^{9}$ Ibid 33.
} 
First I would argue that restrictions based on discrimination on grounds of sexual orientation do not pass Rawls' test of what people would decide behind the veil of ignorance, as no rational participant would decide in favour of discrimination on grounds of an inherent human characteristic, in case it transpires that they have that characteristic in the future society. Section 5 of the Marriage Act 1961 (Cth) limits the right to marry in that it restricts the choice of marriage partner to persons of the opposite sex.

Some opponents of same-sex marriage argue that the limitation of marriage to opposite-sex couples does not restrict a right to marry, but rather a right to enter into a transaction, and that there is no inherent human right to enter into transactions. Yet even if one were to characterise the restriction as one relating to enter into a transaction, the argument against marriage equality still fails the Rawlsian test: This can be demonstrated if one considers analogous questions such as whether people same-sex orientation should be allowed driver's licences or should be allowed to transfer immovable property. Those, like marriage, are everyday transactions which require state sanction. The rational person recoils at the suggestion that the state should discriminate on grounds of sexual orientation in exercising those types of licensing power. Why then should marriage be treated any differently? Since marriage is in its essence a contract (which has an additional religious dimension only among a section of society) why should sexual orientation be a barrier to entry into it? When the issue is cast in these terms, it becomes apparent that the denial to same-sex couples of the capacity to enter into a contract offends against the right to equality.

The other ground upon which I would argue that the exclusion of same-sex couples from the provisions of the Marriage Act 1961 (Cth) fails the Rawlsian test is that it infringes the right to personal autonomy. Here it is useful to refer to a number of United States Supreme court decisions. The first of these, now more than 50 years old, was foundational in establishing a right to personal autonomy in United States constitutional law. In 1961, Estelle Griswold opened a family planning clinic in New Haven, Connecticut. The clinic operated for only ten days, because Griswold and the doctor who was its medical director were arrested, charged and convicted under a statute which made it a criminal offence to use contraceptives, and made liable as accessories anyone, such as Griswold, who aided or abetted their use. The case ultimately reached the United States Supreme Court, and in Griswold $v$ Connecticut, ${ }^{10}$ the court held that by regulating the private conduct of individuals (the clinic's customers) the statute infringed the right to privacy - here used in the broad sense of autonomy to make personal choices - impliedly protected by the Fifth, Ninth and Fourteenth Amendments to the United States Constitution, and that the statute was therefore invalid. ${ }^{11}$ The idea that the legislature should interfere in the most intimate areas of human interaction by limiting the autonomy of consenting adults to make decisions relating to their sexual conduct attracted strong criticism from the court, which commented that the law raised the spectre of the police searching the bedroom for signs of the use of contraceptives.

Underlying the arguments on each side of Griswold is a clash between positivism and rights ${ }^{12}$ in that the case confronts us with the question of whether there are some interests that should be protected from interference even by laws passed by a democratically elected legislature. Positivists would argue that procedurally-correct enactment is the sole sufficient condition for the validity of a law. Their response to the question presented by Griswold would be that if the citizens of Connecticut, acting through a majority of their representatives, thought that people should not be able to use contraceptives, that law would be valid. Yet under a rights-based approach, such a view would be rejected on the basis that people's inherent human dignity entitles them to a zone of liberty, inviolate even from the will of a majority of their fellow citizens. The plaintiffs in Griswold were fortunate in that the United States has a Bill of Rights against which legislation can be challenged. By contrast, if a case such as Griswold arose in Australia, the courts would have no option but to affirm the validity of the statute because Australia has no Bill of Rights to control the Commonwealth or State Parliaments. Nevertheless, the fact that there is no Bill of Rights through which to obtain a remedy as in Griswold does not change the fact that the fundamental question of principle facing Australia as it grapples with the same-sex marriage issue is the same as that which confronted the United States Supreme Court - namely, where is the boundary between the liberty of the individual and the will of society? It is this that parliamentarians need to engage with in determining whether the right to marry should be extended to same-sex couples.

Unfortunately, rights-based analysis has been conspicuous by its absence from the same-sex marriage debate. As

\footnotetext{
${ }^{10}$ (1965) 381 US 479.

${ }^{11}$ For a discussion of the development of the right to privacy in the sense of autonomy in United States law see Feinberg, J. (1986). Harm to Self. New York: Oxford University Press at 87-94.

${ }^{12}$ For a succinct outline of the debate between natural lawyers and positivists see Harris, J.W. (2004) Legal Philosophies (2 ${ }^{\text {nd }}$ ed.). Oxford: Oxford University Press at 14-20.
} 
is further discussed in Part 6 below, many politicians have approached the question from the perspective of their own particular moral values - and in this, the debate on same-sex marriage in Australia strongly echoes the Hart / Devlin debate on the decriminalisation of homosexual intercourse in the United Kingdom in the 1960's. ${ }^{13}$ Few have approached the question from the perspective that, in the absence of any demonstrable harm, matters of personal choice are not the state's business in a free society. Or, to put it as the US Supreme Court did in Griswold, the individual is entitled to a 'zone of privacy ${ }^{14}$ which should become increasingly immune from state control the more intimate the choices that are involved.

The reasoning adopted in Griswold was central to the Supreme Court's decision on same-sex marriage in Obergefell v Hodges. ${ }^{15}$ In that case, drawing on the doctrine established in Griswold, Kennedy $\mathrm{J}$ held that the Due Process clause of the Fourteenth Amendment extends to 'personal choices central to individual dignity and autonomy, including intimate choices that define personal identity and beliefs ${ }^{16}$ and that since "the right to personal choice regarding marriage is inherent in the concept of individual autonomy, ${ }^{17}$ the right to autonomy must extend to the choice of whom to marry. The court held that the prohibition of same-sex marriage also infringed the Equal Protection clause of the Fourteenth Amendment in that it unjustifiably discriminated between same-sex and different-sex couples. ${ }^{18}$ Finally, the court addressed the argument that issues such as same-sex marriage should be left to legislatures, saying that the freedom to exercise fundamental rights should not be contingent on democratic process ${ }^{19}$ and that 'An individual can invoke a right to constitutional protection when he or she is harmed, even if the broader public disagrees and even if the legislature refuses to act', because 'fundamental rights may not be submitted to a vote; they depend on the outcome of no elections. ${ }^{20}$

To date 23 jurisdictions have changed their law so as to permit same-sex marriage, either through court decisions, legislation or constitutional amendment. ${ }^{21}$ Among these are countries such as Ireland, Spain, France, Argentina, Colombia and Brazil, where legalisation was achieved despite the fact that the Roman Catholic church has significant social influence. It is therefore ironic that in Australia, which is a far more secular country in which the 2016 census revealed that religious affiliation is on the decline, ${ }^{22}$ marriage equality has yet to be achieved.

The real crux of the issue of same-sex marriage issue, which opponents of marriage equality have studiously avoided is, therefore, the question of where the boundary lies between the preferences of majorities on the one hand and the autonomy of the individual on the other. Given that the choice of marriage partner is one of the most intimate choices we make in life, there clearly is no justification for the state to enter into this area so as to deny persons of the same sex the right to marry each other. Indeed, such a prohibition puts one in mind of the Prohibition of Mixed Marriages Act ${ }^{23}$ enacted in South Africa in 1949, which prohibited people of different races from getting married. If we would justifiably condemn a law which denied access to marriage on grounds of race, should we not also condemn a law which denies access on grounds of sexual-orientation?

\section{Would Recognition of Same-Sex Marriage Lead to an Infringement of Rights?}

Having established that denial of the right to enter into same-sex marriages offends against the rights to equality and to autonomy, the next stage in our inquiry is whether recognition of same-sex marriage would infringe countervailing rights, which would lead to the conclusion that, under Mill's analysis, that same-sex marriage causes harms and should therefore not be permitted. Would marriage equality cause harms in the form of the infringement of the rights of others?

\footnotetext{
${ }^{13}$ See Devlin, P. (1965). The Enforcement of Morals. London: Oxford University Press and Hart, H.L.A. (1963) Law, liberty and morality. London: Oxford University Press.

14 (1965) 281 US 479, 484 per Douglas J.

15576 U.S. (2015).

${ }^{16}$ Ibid $1-2$.

${ }^{17}$ Ibid 12.

18 Ibid 19-22.

19 Ibid 23-26.

${ }^{20}$ Ibid 24.

${ }^{21}$ Masci, D., Sciupac, E. and Lipka, M. (30 June 2017). Gay marriage around the world. Pew Research Center. Retrieved from http://www.pewforum.org/2017/06/30/gay-marriage-around-the-world-2013/

${ }^{22}$ Hutchens, G. (27 June 2017). Australian census: religious affiliation falls as population changes rapidly. The Guardian. Retrieved from https://www.theguardian.com/australia-news/2017/jun/27/australian-census-religious-affiliation-falls-as-population-changes-rapidly

${ }^{23}$ No. 55 of 1949.
} 


\subsection{Same-sex Marriage and Its Effect on Heterosexual Marriage}

First we can dismiss the bizarre argument that by recognising same-sex marriage, the rights of couples in heterosexual marriages would be infringed. A rational basis for this argument has never been presented, and it is difficult to see how it could be - unless its proponents believe that the opportunity to contract a same-sex marriage would somehow entice people away from heterosexual unions, a line of reasoning which would be valid only if one believed that sexual orientation was chosen rather than innate.

\subsection{Same-sex Marriage and Freedom of Religion}

Could the legalisation of same-sex marriage infringe freedom of religion? Section 116 of the Constitution guarantees religious freedom, including by prohibiting the establishment of any official religion. The implication of this is that public policy should be neutral as between religions and should be framed on secular principles. Restricting marriage to different-sex couples reflects a particular religious perspective, and thus imposes a religious view on others, contrary to s 116. It is therefore the prohibition of same-sex marriage, not its legalisation, which constitutes a denial of religious freedom.

But if same-sex marriage was permitted, are there circumstances in which religious freedom might be infringed in the sense that people found themselves in the position of having to choose between the dictates of their religion prohibiting same-sex unions and compliance with the law? The only occasion on which a clash between religious belief and compliance with the law has been considered by the High Court is the case of Krygger $v$ Williams ${ }^{24}$ which involved a Jehovah's Witness who claimed exemption from a stature requiring military training on the ground that his religious beliefs forbade him from bearing arms. With respect, the High Court's analysis was superficial to say the least, Barton J holding ${ }^{25}$ that the appellant's s 116 rights had not been infringed because the law requiring that he undergo military training did not prohibit him from practising his religion. The court did not properly grapple with the issue of whether the very act of enrolment in the armed services infringed the appellant's freedom of religion.

The religious freedom issue requires serious consideration in the same-sex marriage debate. Three circumstances in which a clash could occur between religious beliefs and the requirements of the law need to be considered. Each of them revolves around the question of where the boundary lies between 'private' relationships in which discrimination is permissible and 'public' ones where it is not.

\subsubsection{Marriage Celebrants}

The first circumstance involves cases where ministers of religion, acting in their capacity as marriage celebrants, would find it inconsistent with the tenets of their religion to marry same-sex couples. Religions are self-evidently private associations. Membership is contingent upon adherence to a set of beliefs. For this reason, religions are exclusionary (or at least, potentially exclusionary) organisations. A religion's beliefs may appear irrational and even discriminatory to outsiders. But so long as adherence to the religion is voluntary, the state has no role in proscribing the beliefs it propounds, or in determining who may or may not be accepted as a member to whom ministers of religion should provide services. This is already reflected in the law in Australia: Section 47 of the Marriage Act 1961 (Cth) states that the Act imposes no obligation on ministers of religion to solemnise marriages. Every Bill for the legalisation of same-sex marriage that has been introduced into Parliament has preserved the position in $\mathrm{s} 47$ so as to place ministers of religion under no obligation to officiate at such unions. ${ }^{26}$

\subsubsection{Businesses}

The second circumstance which needs to be considered is the argument advanced by conservative religious politicians that respect for freedom of religion requires that business people be entitled to decline involvement in same-sex unions. ${ }^{27}$ Liberal (now Conservative) Senator Cory Bernardi said that all businesses should be able to

\footnotetext{
${ }^{24}$ (1912) 15 CLR 366.

25 Ibid, 372-3.

26 See links the to the various

http://parlinfo.aph.gov.au/parlInfo/download/legislation/bills/r5512_first-reps/toc_pdf/15141Entsch.pdf;fileType=application\%2Fpdf

${ }^{27}$ Karp, P. (14 September 2016). Marriage equality: Law would protect 'conscientious objectors' who reject same-sex weddings. The Guardian. Retrieved from https://www.theguardian.com/australia-news/2016/sep/14/marriage-equality-law-would-protect-conscientious-objectors-who-reject-gay-wed dings
} 
discriminate 'for any or no reason' (including against same-sex couples), ${ }^{28}$ while Liberal-National MP, George Christensen, said that venue-owners, bakers and photographers should have the right to refuse custom to same-sex couples. ${ }^{29}$ Does the argument that proprietors of businesses have the right to discriminate against same-sex couples on religious grounds have any validity?

A case of this type recently arose in the United States: In Mullins v Masterpiece Cake Shop ${ }^{30}$ the owner of a wedding-cake shop refused to make a cake for a same-sex couple. The Colorado Court of Appeals found that in so doing, the respondent had breached the Colorado Anti-Discrimination Act ${ }^{31}$ which prohibits discrimination on grounds of sexual orientation in places of 'public accommodation' - broadly defined in the Act as any place where a business offers goods or services to the public. The case has now been appealed to the United States Supreme Court.

This circumstance is obviously different from that where a minister of religion refuses to officiate at a union between a same-sex couple. One of the hallmarks of a religion is that it is a defined community based on acceptance of a set of beliefs - which of necessity means excluding those who do not accept those beliefs. In other words, the right to exclude non-believers - on any grounds - can be said to be fundamental to the capacity of a religious group to define itself. It is for this reason that religious ministers should not be required to officiate at marriages between same-sex couples. By contrast, the raison d'être of business is to solicit custom from the public and so rejection of customers by a business on discriminatory grounds such as race, gender or sexual orientation (as compared, for example, to exclusion on the ground of lack of creditworthiness), is not only unnecessary for engagement in business but is indeed surely antithetical to it. Such conduct thus causes offence which is all the more egregious because it is gratuitous. This exposes the fatal flaw in the argument that religious freedom justifies withholding custom from same-sex couples: Unlike in the case of a religious celebrant performing a sacrament, the sale of a cake or the taking of a photograph is not a religious act. That is why non-religious marriage celebrants, cake-makers, photographers and limousine drivers et cetera ought not to be allowed to discriminate in the provision of what are simply commercial services. There is no consideration of conscience which logically justifies discrimination against people on the ground of their sexual orientation.

The duty to serve the public without discrimination has long existed under the common law doctrine of "common callings', according to which operators of businesses which provided services that were necessary for goods to get to market - prime examples being carriers of goods and people, farriers and inn-keepers et cetera - were obliged to provide their services at a reasonable price and on a non-discriminatory basis. ${ }^{32}$ More recently however, in jurisdictions which have constitutional provisions prohibiting discrimination, plaintiffs have successfully challenged discrimination in private contractual relationships on the ground that they infringe statutes enacted in support of the right to equality. Courts have pointed to the affront to dignity that is caused by discrimination in finding that it is unlawful for businesses to discriminate on prohibited grounds such as race, gender, disability and sexual orientation.

This was the basis of a line of decisions on private contractual relationships by the United States Supreme Court beginning during the civil rights era: ${ }^{33}$ In Shelley $v$ Kraemer, ${ }^{34}$ for example, the court held that racially discriminatory covenants incorporated into housing contracts by private developers were unenforceable under the Equal Protection clause of the Fourteenth Amendment. In Boynton v Virginia, ${ }^{35}$ the court held that it was

\footnotetext{
${ }^{28}$ Karp, P. and Meade, A. (28 September 2016). Cory Bernardi says all businesses should be free to discriminate against anyone. The Guardian. Retrieved from https:/www.theguardian.com/australia-news/2016/sep/28/cory-bernardi-says-all-businesses-should-be-free-to-refuse-service-to-anyone

${ }^{29}$ Karp, P. (29 September 2016). Warren Entsch rejects conservatives' call for 'right to reject' gay weddings. The Guardian. Retrieved from https://www.theguardian.com/australia-news/2016/sep/29/warren-entsch-rejects-conservatives-call-for-right-to-refuse-gay-weddings

302015 COA $115 ; 370$ P.3d 272

${ }^{31}$ COLO. REV. STAT. 24-34-601(2).

32 See, for example, Constantine v Imperial Hotels Ltd [1944] KB 693 and Odom v East Avenue Corp 178 Misc. 373, 34 N.Y.S. 2d 312 (1942), cases from the United Kingdom and the United States respectively, in which black patrons successfully sued hotels under the doctrine having been denied accommodation on grounds of race. For a comprehensive discussion of the doctrine as it has operated in the United States see Note (1989). The Anti-Discrimination Principle in the Common Law. Harvard Law Review102, 1993-2013. See also Grey, K. (2010). Regulatory Property and the Duty of Quasi-Public Trust. Sydney Law Review 32, 237-67 at 247-8 where numerous cases from the United Kingdom and the United States are cited in the footnotes.

${ }^{33}$ For a discussion of the amenability of private contractual relationships to anti-discrimination law see Van Dyke, V. (1990). Equality and Public Policy. Chicago: Nelson-Hall at 149-57.

34334 U.S. 1 (1948).

35364 U.S. 454 (1960).
} 
unlawful for a bus company to discriminate between passengers along racial lines in its provision of facilities at bus terminals. In Heart of Atlanta Motel Inc. v United States ${ }^{36}$ the court held that a motel breached federal anti-discrimination law in denying accommodation to African-American travellers. The mere fact that these cases involved contractual relationships did not immunise them from the reach of anti-discrimination law. In other words, although consensus lies at the heart of contracts, which can therefore be said to be 'private' in nature, once a business offers goods or services to the public, it steps into the public arena and breaches equality rights if it discriminates on a prohibited ground. For this reason, the argument that the religious beliefs of a person engaging in public commerce entitle them to discriminate on grounds of sexual orientation has no more validity than did the argument that the right to hold segregationist political beliefs entitled business owners to refuse custom to African Americans in the United States in the 1950s.

In Australia, discrimination on grounds of sexual orientation is prohibited by s $5 \mathrm{~A}$ of the Sex Discrimination Act 1984 (Cth). In addition, 6 of the Act prohibits discrimination on grounds of marital and relationship status. These provisions, as read with s 22 of the Act, which prohibits discrimination in the provision of goods, services and facilities, would prohibit businesses from engaging in discrimination against same-sex couples. State and Territory statutes also contain anti-discrimination provisions. Section10(3) of the Commonwealth Act states that that Act does not intend to exclude the operation of State and Territory laws, so long as the latter are capable of operating concurrently with the Commonwealth Act. State and Territory legislation closely parallels the Commonwealth Act. Thus, to take New South Wales as an example, s 47 of the Anti-Discrimination Act 1977 (NSW) prohibits discrimination on grounds of marital or domestic status in the provision of goods and services, while s 49ZP similarly prohibits discrimination on grounds of homosexuality.

As it currently stands, Australian law is therefore consistent with the notion that private contractual relationships should be subject to equality rights and so the law would prohibit businesses from discriminating against same-sex couples. I would argue that that position should be maintained.

\subsubsection{Religious Bodies Operating Businesses}

The third, more difficult circumstance that needs to be considered is where religious organisations themselves operate institutions which, on the face of it, engage in public business - schools and old-age facilities being obvious examples. Are such institutions to be classified as 'private', and thus free to discriminate, or should they be classified as 'public' and thus subject to anti-discrimination law in the same way as are other businesses? Should a religious school be permitted to prohibit parents in a same-sex relationship from enrolling their children at the school? Should an old-age facility owned by a religious body be entitled to refuse to accommodate same-sex couples in married quarters of that facility? One commentator who is both a legal academic and a Catholic priest said that these questions should be answered in the affirmative - although hoping that charity would lead school and old-age homes not to avail of legal rights to exclude. ${ }^{37}$ Of course the uncertain operation of charitable considerations cannot be determinative of the answer to a legal issue - the law will have to adopt a position on whether discrimination is lawful or not.

I would argue that an initial key distinction that needs to be made is between institutions which are owned by religious bodies and where admission is genuinely restricted to members of that religion on the one hand and those where the institution offers its services to the public at large on the other. In the former case, even though the institution is engaged in business, the exclusionary manner in which it defines its clientele takes it out of the public realm and into the private, in which circumstances freedom to discriminate should be permitted. The key condition here is that the institution must genuinely restrict the operation of its business to members of the religion - if the institution is to enjoy the benefit (as it sees it) of the right to discriminate, it should not be permitted to cross the barrier between private and public business by seeking custom from non-believers, which commercial considerations might tempt it to do.

In contrast to institutions which restrict their custom to members of a religion, many institutions, while operated by religious bodies, accept custom from the public at large. Catholic and other religious schools are a good example of this - although established as places where parents can have their children educated in accordance with the tenets of their faith, in practice most such schools accept students from families who are not adherents. The fact that in such instances parents are advised that their children will have to attend classes in which instruction in religious doctrine is provided does of course not mean that they or their children thereby become

\footnotetext{
36379 U.S. 241 (1964).

${ }^{37}$ Brennan, F. (12 August 2015). The Precondition for Commonwealth Recognition of Same Sex Marriage, ABC Religion and Ethics, Retrieved from http://www.abc.net.au/religion/articles/2015/08/12/4291743.htm
} 
members of the church. I would argue that where a business operation owned by a religious organisation enjoys the commercial advantage of soliciting custom from all-comers rather than only from religious adherents, the rule prohibiting discrimination by public businesses discussed in 5.2.2 above should apply.

The law on exemptions from anti-discrimination law for institutions run by religious organisations differs between jurisdictions in Australia. So far as the Commonwealth is concerned, s 37(1)(d) of the Sex Discrimination Act 1984 (Cth) exempts from the provisions of the Act any

..act or practice of a body established for religious purposes, being an act or practice that conforms to the doctrines, tenets or beliefs of that religion or is necessary to avoid injury to the religious susceptibilities of adherents of that religion.

It should however be noted that section 37(2)(a) excludes from the ambit of the exemption the provision of aged-care services where those services are funded by the Commonwealth.

Section 38(3) of the Commonwealth Act permits educational institutions established for religious purposes to

..discriminate against another person on the ground of the other person's sexual orientation, gender identity, marital or relationship status or pregnancy in connection with the provision of education or training by an educational institution that is conducted in accordance with the doctrines, tenets, beliefs or teachings of a particular religion or creed, if the first-mentioned person so discriminates in good faith in order to avoid injury to the religious susceptibilities of adherents of that religion or creed

Sections 37(1)(d) and 38(3) seem to contemplate that, in order to avail of the exemptions they provide, religious bodies would have to prove that an act or practice was required by their doctrine - which raises the invidious prospect of courts determining what the tenets of a religion are.

At State and Territory level, each jurisdiction carves out exceptions to their general prohibitions on discrimination, although generally replicating the provisions contained in the Commonwealth Act. Space does not permit a survey of the law of all jurisdictions, but two examples will suffice: In New South Wales, s 56(c) of the Anti-Discrimination Act 1977 (NSW) is identical to s 37(1)(d) of the Commonwealth Act. In the case of aged-care facilities, s 59 provides that accommodation for aged persons may be restricted on grounds of sex, marital status or race - although one should note that, if an aged-care facility received Commonwealth funding, it would not be able to discriminate on grounds of marital status because of s 37(2)(a) of the Commonwealth Act. In Victoria, s 82(2) of the Equal Opportunity Act 2010 (Vic) is cast in similar terms to s 37(1)(d) of the Commonwealth Act, in that it religious bodies to discriminate on grounds of religious belief, sex, sexual orientation, lawful sexual activity, marital status, parental status or gender identity. Section 83(2) makes the same provision in relation to schools run in accordance with religious principles. It should however be noted that ss 82 and 83 must be read in light of s 84 , which states that discrimination justified by religious principles means discrimination which is reasonably necessary for a person to comply with the doctrines, beliefs or principles of their religion - which again raises the prospect of curial determination of what a religion's doctrines require.

None of these provisions, either Commonwealth or State, distinguish between institutions which restrict entry to adherents of a religion from those which offer services to the public as a whole. To that extent, the exemptions offered by these statutes are too broad. On the other hand, they are too narrow in that they envisage judicial inquiry into what is and is not part of a religion's beliefs. I would argue that the Commonwealth should, in enacting legislation legalising same-sex marriage, amend the Sex Discrimination Act 1984 (Cth) so as to provide that religious bodies and institutions operated by them could discriminate on grounds of religious belief, sex, sexual orientation, lawful sexual activity, marital status, parental status or gender identity, if they offer their services only to their adherents. There should also be no statutory test of whether such discrimination was required by the tenets of the religion. However, where such institutions offer services to the public at large, discrimination should not be permitted. This would give legislative effect to the distinction between private and public business activities of religious entities in accordance with the principles discussed above. This would also provide an opportunity to ensure a uniform national approach to the question, as amendments to the Commonwealth Act could be drafted in such a manner as to declare that they over-rode inconsistent State and Territory laws on this topic.

\section{The Political Process}

The final issue that needs to be addressed is the way in which same-sex marriage has been addressed by successive Australian governments. Although it might have been hoped that the debate would have involved a contest of ideas, the positions adopted by the major political parties have been driven by a combination of social conservatism and political expediency. 
The issue of same-sex marriage has became increasingly controversial following the amendment to the Marriage Act 1961 (Cth) by the conservative Liberal-National coalition government of John Howard in 2004. The amendment, which was designed to thwart any judicial interpretation of 'marriage' as that term was used in the Act so as to include same-sex marriage, inserted into the Act a definition of marriage as 'the union of a man and a woman to the exclusion of all others, voluntarily entered into for life'. The measure was supported by the opposition Labor party, which feared losing support among socially-conservative working-class voters if it was seen to support same-sex marriage. ${ }^{38}$ Labor maintained this position when it came to power in 2007 under the leadership of Kevin Rudd, ${ }^{39}$ and subsequently under the Prime-Ministership of Julia Gillard. ${ }^{40}$ It was a testament to how strong party discipline is in Australia that the country witnessed the extraordinary sight of Senator Penny Wong, herself openly gay, expressing public support for Labor's position. ${ }^{41}$ Labor's stance changed in 2011 after a bitter internal battle when the party adopted recognition of same-sex marriage as its official policy, while stating that MPs would be allowed a conscience vote on the issue in Parliament until 2019, whereafter voting in favour of same-sex marriage would become mandatory ${ }^{42}$ Nevertheless, even after Labor's volte face, a Bill for the recognition of same-sex marriage introduced in 2012 failed to pass Parliament due to the combined votes of Liberal and National MPs (who were subject to a party whip) and those of right-wing Labor MPs exercising their conscience vote. ${ }^{43}$

In 2013, the Liberal-National coalition was elected to power under Prime Minister Tony Abbott. By 2015 it had become apparent that the balance of sentiment in Parliament had changed, and that if Liberal-National MPs were allowed a free vote then they, in combination with those Labor parliamentarians supporting marriage equality, would be likely to succeed in passing a Bill legalising same-sex marriage. However, a vote of the Liberal-National coalition caucus rejected a proposal to allow a free vote, and Abbott said that the matter would instead be put to a plebiscite after the next election, scheduled for $2016 .{ }^{44}$ This move was widely seen as cynical, ${ }^{45}$ pandering to the religious right within the coalition and as designed to delay what would have been an inevitable approval of same-sex marriage by Parliament - 'kicking for touch', to adopt a sporting analogy. No justification was offered for why the issue of same-sex marriage, among the many other pressing issues facing the country, should be singled out for determination by plebiscite, a procedure last used in Australia in 1916. When Malcolm Turnbull replaced Tony Abbott as Prime-Minister through a party coup in 2016, he upheld the policy of holding a plebiscite, despite his being from the liberal wing of the party and being personally in favour of same-sex marriage. Whatever room for manoeuvre Turnbull might have had was reduced in scope after the 2016 election, when his government was returned to power with only a single seat majority in the House of Representatives, which meant that he could not afford to alienate the right wing of his party by abandoning the idea of a plebiscite.

The prospect of a plebiscite on same-sex marriage was controversial, and gave added opportunity for the religious right to play a spoiling role: Parliament is not bound by the result of a plebiscite, and so even if a proposal to change the law was approved by voters, it would still have to be enacted by Parliament. Furthermore, conservative members of the Coalition parties stated that even if the proposal achieved a national majority in a plebiscite, they would not regard themselves as being bound to vote in favour of same-sex marriage when the measure came before Parliament, and would vote according to the result in their individual electorates - thus

\footnotetext{
${ }^{38}$ Johnson, C. (2013). Fixing the meaning of marriage: political symbolism and citizen identity in the same-sex marriage debate. (2013) 27 Continuum: Journal of Media \& Cultural Studies 242-53.

39 Wright, T. and Nicholson, B. (24 October 2007). Outrage at Rudd's same-sex marriage stance' The Age. Retrieved from http://www.theage.com.au/news/federalelection2007news/outrage-at-rudds-samesex-marriage-stance/2007/10/23/1192941066209.html

${ }^{40}$ Levy, M. (10 May 2012). I won’t vote for it: PM stands firm on same-sex marriage. The Sydney Morning Herald. Retrieved from http://www.smh.com.au/federal-politics/political-news/i-wont-vote-for-it-pm-stands-firm-on-gay-marriage-20120510-1ye2e.html

41 Abrahams, S. (25 July 2010). Penny Wong labelled a hypocrite. Star Observer. Retrieved from http://www.starobserver.com.au/news/national-news/new-south-wales-news/wong-facing-marriage-backlash/28541

42 ABC News. (23 January 2012). Labor decides on conscience vote for same-sex marriage. Retrieved from http://www.abc.net.au/news/2011-12-03/labor-votes-for-conscience-vote-on-same-sex-marriage/3710828

43 Cullen, S. (19 September 2012). Lower house votes down same-sex marriage bill. ABC News. Retrieved from http://www.abc.net.au/news/2012-09-19/same-sex-marriage-bill-voted-down/4270016

${ }^{44}$ Scott, S. (12 August 2015). Controversial vote on same-sex unions set to cause rift in coalition. The Courier Mail. Retrieved from http://www.couriermail.com.au/news/queensland/controversial-debate-on-samesex-unions-set-to-cause-rift-in-coalition/news-story/1580147a d2eea350365d09ce9dad5d45

${ }^{45}$ Riordan, P. and Coorey, P. (12 August 2015). Gay marriage plebiscite a 'delaying tactic': Labor. The Australian Financial Review. Retrieved from http://www.afr.com/news/gay-marriage-plebiscite-delaying-tactic-labor-20150811-gix19w
} 
raising the prospect of there effectively being 150 separate plebiscites. ${ }^{46}$ The non-binding nature of a plebiscite, the possibility that coalition members might in any event vote contrary its result, its estimated $\$ 160$ million cost (leading some to label it 'the world's most expensive opinion poll) ${ }^{47}$ and the invidiousness of respect for fundamental freedoms being made contingent on a popular majority, raised the valid question of the utility of holding it. These considerations ultimately led Labor to vote against the plebiscite legislation when it was introduced in 2016, thus ensuring its defeat in the Senate where the government lacked a majority. ${ }^{48}$

The history outlined above shows that decisions by both Labor (at least until 2011) and the Liberal-National coalition have been dictated by pragmatics rather than by principle and have been primarily motivated by a desire to appease the right wing of each bloc. Paradoxically, opinion polls show that $70 \%$ of voters support same-sex marriage, ${ }^{49}$ yet Australia's highly disproportional electoral system ${ }^{50}$ coupled with notorious failures in internal party democracy ${ }^{51}$ which features centralised party control over the selection of candidates ${ }^{52}$ and manipulation of candidate selection through branch-stacking, ${ }^{53}$ makes it easy for factions to achieve a degree of power within the parliamentary parties that is disproportionate to the level of support that their ideas enjoy in the wider community. The history of the same-sex marriage issue has shown that the major determinant of party policy has not been what the principled course is, nor even what course is favoured by the public at large, but rather which course is most likely to lead to a party retaining government and, within parties, which course is likely to enable the leader to retain his or her position. Thus party leaders focus externally on embarrassing their opponents and internally on doing what is necessary to appease powerful factions. This is why the focus of political attention has been on pragmatic power considerations, rather than on matters of principle.

It is for this reason that debate on same-sex marriage has been notable for the absence of intellectual discussion of concepts such as the right to individual autonomy. This is particularly true of the religious right who - perhaps unsurprisingly given the weakness of their position when considered from a fundamental rights perspective have studiously avoided theoretical debate. Instead their most prominent representatives have enunciated views such as that by Senator Eric Abetz who opposes same-sex marriage inter alia because he believes that gay people can 'turn straight ${ }^{54}$ and Senator Cory Bernardi, who equated same-sex intercourse with bestiality. ${ }^{55}$ Other arguments have been equally bizarre, such as that by Minister for Agriculture, Barnaby Joyce, who said that if Australia legalised same-sex marriage it would be viewed as 'decadent' by Asian countries, linking that to the fact that Australia exports cattle to Indonesia - presumably meaning that Indonesia would not want to take cattle from a country recognising same-sex marriage. ${ }^{56}$

Both major parties, fearful of their socially conservative elements, have acted out of expediency in refusing to legalise same-sex marriage. Had their leaders taken a principled, bi-partisan stance motivated by respect for human dignity and autonomy, there is little doubt that sufficient cross-party support could have been mustered

\footnotetext{
${ }^{46}$ Taylor, L. (27 January 2016). Eric Abetz: Coalition MPS will not be bound by plebiscite on marriage equality. The Guardian. Retrieved from

https://www.theguardian.com/australia-news/2016/jan/27/eric-abetz-coalition-mps-will-not-be-bound-by-plebiscite-on-marriage-equality

47 Burke, L. (29 August 2016). Is the plebiscite dead in the water? News Ltd. Retrieved from http://www.news.com.au/lifestyle/gay-marriage/is-the-plebiscite-dead-in-the-water/news-story/b95e7138825cf34068ff85ff9d3412a1

48 Burke, L. (11 October 2016). Labor votes to block same-sex marriage plebiscite. News Ltd. Retrieved from http://www.news.com.au/national/politics/labor-votes-to-block-samesex-marriage-plebiscite/news-story/734710be1cd4e19b1cd2460e0c73a8 65

${ }^{49}$ Anderson, F. (1 July 2016). Election 2016: Majority of voters would say yes in gay marriage plebiscite. Australian Financial Review. Retrieved from http://www.afr.com/news/politics/election-2016-majority-of-voters-would-say-yes-in-gay-marriage-plebiscite-20160701-gpwg3z

${ }^{50}$ Harris, B. (2016). Does the Commonwealth Electoral Act Satisfy the Requirement that Representatives be 'Directly Chosen' by the People? Journal of Politics and Law 9, 78-92.

51 Johns, G. (2000). Party Democracy: An Audit of Australian Parties. Australian Journal of Political Science 35, 401-25.

${ }_{52}$ Miragliotta, N. (2013). Explaining the (Lack of) Use of Radical Candidate Selection Methods by Australia's Major Parties. Australian Journal of Politics and History 59, 113-26.

${ }^{53}$ Gauja, A. (2010). Political Parties and Elections - Legislating for Representative Democracy (2010, Farnham: Ashgate Publishing, at $118-20$

${ }^{54}$ Duffy, N. (4 April 2017). Senator opposes same-sex marriage because gay people 'can turn straight. Pink News. Retrieved from http://www.pinknews.co.uk/2017/04/04/senator-opposes-same-sex-marriage-because-gay-people-can-turn-straight/

${ }^{55}$ Coorey, P., White, J. and Gardiner, S. (19 September 2012). Bernardi under fire for bestiality comments. The Age. Retrieved from http://www.theage.com.au/federal-politics/political-news/bernardi-under-fire-for-bestiality-comments-20120918-265dg\#ixzz2WXrSBWOs

${ }^{56}$ Roberts, G. (10 July 2015). Indonesia dismisses suggestion relations with Australia could be affected if same-sex marriage legalised. $A B C$ News. Retrieved from http://www.abc.net.au/news/2015-07-10/indonesia-australia-relations-same-sex-marriage-legalised/6609058
} 
from among the socially progressive ranks of both sides of the House to enable a Bill legalising same-sex marriage to pass Parliament. That this has not happened is an indictment of the way politics is conducted in Australia.

\section{Conclusion and Prospects for the Future}

The issue of with whom a person may marry raises fundamental questions relating to the power of the state to regulate intimate relationships or, to put it differently, the extent to which the state may intrude upon the right to personal autonomy. The fact that Australia does not have a full Bill of Rights in its Constitution means that the issue of same-sex marriage falls to Parliament, where the focus has been on pragmatics rather than on principle. The likelihood therefore is that change will occur only when Labor wins power and its members vote in accordance with the party policy which comes into effect in 2019, binding them to vote in favour of same-sex marriage.

\section{References}

ABC News. (2012, January 23). Labor decides on conscience vote for same-sex marriage. Retrieved from http://www.abc.net.au/news/2011-12-03/labor-votes-for-conscience-vote-on-same-sex-marriage/3710828

Abrahams, S. (2010, July 25). Penny Wong labelled a hypocrite. Star Observer. Retrieved from http://www.starobserver.com.au/news/national-news/new-south-wales-news/wong-facing-marriage-backlas $\mathrm{h} / 28541$

Anderson, F. (2016, July 1). Election 2016: Majority of voters would say yes in gay marriage plebiscite. Australian Financial Review. Retrieved from http://www.afr.com/news/politics/election-2016-majority-of-voters-would-say-yes-in-gay-marriage-plebisci te-20160701-gpwg3z

Brennan, F. (2015, August 12). The Precondition for Commonwealth Recognition of Same Sex Marriage. $A B C$ Religion and Ethics. Retrieved from http://www.abc.net.au/religion/articles/2015/08/12/4291743.htm

Burke, L. (2016, August 29). Is the plebiscite dead in the water? News Ltd. Retrieved from http://www.news.com.au/lifestyle/gay-marriage/is-the-plebiscite-dead-in-the-water/news-story/b95e713882 $5 \mathrm{cf} 34068 \mathrm{ff} 85 \mathrm{ff} 9 \mathrm{~d} 3412 \mathrm{a} 1$

Burke, L. (2016, October 11). Labor votes to block same-sex marriage plebiscite. News Ltd. Retrieved from http://www.news.com.au/national/politics/labor-votes-to-block-samesex-marriage-plebiscite/news-story/73 4710be1cd4e19b1cd2460e0c73a865

Coorey, P., White, J., \& Gardiner, S. (2012, September 19). Bernardi under fire for bestiality comments. The Age. Retrieved from http://www.theage.com.au/federal-politics/political-news/bernardi-under-fire-for-bestiality-comments-2012 0918-265dg\#ixzz2WXrSBWOs

Cullen, S. (2012, September 19). Lower house votes down same-sex marriage bill. ABC News. Retrieved from http://www.abc.net.au/news/2012-09-19/same-sex-marriage-bill-voted-down/4270016

Devlin, P. (1965). The Enforcement of Morals. London: Oxford University Press.

Duffy, N. (2017, April 4). Senator opposes same-sex marriage because gay people 'can turn straight. Pink News. Retrieved from http://www.pinknews.co.uk/2017/04/04/senator-opposes-same-sex-marriage-because-gay-people-can-turn-s traight/

Feinberg, J. (1986). Harm to Self. New York: Oxford University Press.

Gauja, A. (2010). Political Parties and Elections - Legislating for Representative Democracy . Farnham: Ashgate Publishing, at 118-20.

Grey, J., \& Smith, G. W. (Eds.). (1991). J S Mill 'On Liberty' in Focus. London: Routledge.

Grey, K. (2010). Regulatory Property and the Duty of Quasi-Public Trust. Sydney Law Review, 32, 237-67.

Harris, B. (2016). Does the Commonwealth Electoral Act Satisfy the Requirement that Representatives be 'Directly Chosen' by the People? Journal of Politics and Law, 9, 78-92. https://doi.org/10.5539/jpl.v9n4p78

Harris, J. W. (2004). Legal Philosophies (2nd ed.). Oxford: Oxford University Press.

Hart, H. L. A. (1963). Law, liberty and morality. London: Oxford University Press. 
Hutchens, G. (2017, June 27). Australian census: religious affiliation falls as population changes rapidly. The Guardian. https://www.theguardian.com/australia-news/2017/jun/27/australian-census-religious-affiliation-falls-as-po pulation-changes-rapidly

Johns, G. (2000). Party Democracy: An Audit of Australian Parties. Australian Journal of Political Science, 35, 401-25. https://doi.org/10.1080/713649350

Johnson, C. (2013). Fixing the meaning of marriage: political symbolism and citizen identity in the same-sex marriage debate. Continuum: Journal of Media \& Cultural Studies, 242-53. https://doi.org/10.1080/10304312.2013.766308

Karp, P. (2016, September 14). Marriage equality: Law would protect 'conscientious objectors' who reject same-sex weddings. The Guardian. Retrieved from https://www.theguardian.com/australia-news/2016/sep/14/marriage-equality-law-would-protect-conscientio us-objectors-who-reject-gay-weddings

Karp, P. (2016, September 29). Warren Entsch rejects conservatives' call for 'right to reject' gay weddings. The Guardian. Retrieved from https://www.theguardian.com/australia-news/2016/sep/29/warren-entsch-rejects-conservatives-call-for-right -to-refuse-gay-weddings

Karp, P., \& Meade, A. (2016, September 28). Cory Bernardi says all businesses should be free to discriminate against anyone. The Guardian. Retrieved https://www.theguardian.com/australia-news/2016/sep/28/cory-bernardi-says-all-businesses-should-be-freeto-refuse-service-to-anyone

Kirby, M. (2016). The ACT Marriage Equality Case - Losing the Battle but Winning the Constitutional War. Southern Cross University Law Review, 18, 79-91.

Levy, M. (2012, May 10). I won't vote for it: PM stands firm on same-sex marriage. The Sydney Morning Herald. Retrieved from http://www.smh.com.au/federal-politics/political-news/i-wont-vote-for-it-pm-stands-firm-on-gay-marriage20120510-1ye2e.html

Masci, D., Sciupac, E., \& Lipka, M. (2017, June 30). Gay marriage around the world. Pew Research Center. Retrieved from http://www.pewforum.org/2017/06/30/gay-marriage-around-the-world-2013/

Miragliotta, N. (2013). Explaining the (Lack of) Use of Radical Candidate Selection Methods by Australia's Major Parties. Australian Journal of Politics and History, 59, 113-26. https://doi.org/10.1111/ajph.12007

Note. (1989). The Anti-Discrimination Principle in the Common Law. Harvard Law Review, 102, 1993-2013. https://doi.org/10.2307/1341365

Rawls, J. (1972). A Theory of Justice. Oxford: Clarendon Press.

Riordan, P., \& Coorey, P. (2015, August 12). Gay marriage plebiscite a 'delaying tactic': Labor. The Australian Financial Review. Retrieved from http://www.afr.com/news/gay-marriage-plebiscite-delaying-tactic-labor-20150811-gix19w

Roberts, G. (2015, July 10). Indonesia dismisses suggestion relations with Australia could be affected if same-sex marriage legalised. $A B C$ News. Retrieved from http://www.abc.net.au/news/2015-07-10/indonesia-australia-relations-same-sex-marriage-legalised/6609058

Scott, S. (2015, August 12). Controversial vote on same-sex unions set to cause rift in coalition. The Courier Mail. Retrieved

from http://www.couriermail.com.au/news/queensland/controversial-debate-on-samesex-unions-set-to-cause-riftin-coalition/news-story/1580147ad2eea350365d09ce9dad5d45

Taylor, L. (2016, January 27). Eric Abetz: Coalition MPS will not be bound by plebiscite on marriage equality. The Guardian. Retrieved from https://www.theguardian.com/australia-news/2016/jan/27/eric-abetz-coalition-mps-will-not-be-bound-by-pl ebiscite-on-marriage-equality

Van Dyke, V. (1990). Equality and Public Policy. Chicago: Nelson-Hall.

Wright, T., \& Nicholson, B. (2007, October 24). Outrage at Rudd's same-sex marriage stance' The Age. Retrieved 
http:/www.theage.com.au/news/federalelection2007news/outrage-at-rudds-samesex-marriage-stance/2007/ 10/23/1192941066209.html

\section{Copyrights}

Copyright for this article is retained by the author(s), with first publication rights granted to the journal.

This is an open-access article distributed under the terms and conditions of the Creative Commons Attribution license (http://creativecommons.org/licenses/by/4.0/). 